\title{
As Real as the Spice Girls: Representing Identity in Twenty-first Century New Zealand Literature
}

ERIN MERCER

The concept of authenticity has long been inextricable from identity in Aotearoa New Zealand, ever since Allen Curnow famously urged midtwentieth century artists to focus on the local and the specific in order to create an island nation clearly differentiated from Britain. Recent writers, however, particularly in works that have appeared since the turn of the century, are increasingly questioning just what 'authenticity' means in relation to identity. There is a marked contrast between the part-Maori, part-Pakeha protagonist in Keri Hulmes' 1984 novel the bone people, who explains that 'by blood, flesh, and inheritance, I am but an eighth Maori, by heart, spirit, and inclination, I feel all Maori, ${ }^{1}$ and the Fijian New Zealander in Toa Fraser's 1999 play No.2, who insists that her Nanna is 'about as real Fijian as the Spice Girls'. ${ }^{2}$ Writers such as Fraser, Paula Morris and Eleanor Cattan represent identity not as inherent or authentic but as constructed and performed.

When the bone people was first published, Mark Williams noted that it 'stood for literary excellence made locally out of indigenous materials alone' and was perceived as 'something utterly authentic and of this place'. 3 Responses in popular forums such as the Listener stressed the inherent New Zealandness of Hulme's novel by suggesting it revealed a 'flowering of talent which has not been transported from the northern hemisphere' but which grew 'from the breast of Papa' herself. ${ }^{4}$ Its popularity derived from its melding of Maori and European traditions and its depictions of a recognizably New Zealand landscape. One commentator described it as 'the most New Zealand novel I've ever read', ${ }^{5}$ while another identified it as 'the first real New Zealand novel'. ${ }^{6}$ Fifteen years after the bone people's publication, a very different view about what constitutes New Zealand writing was expressed by Toa Fraser. When an interviewer queried the 'cultural drift' of his work - from stories about New Zealand to stories with a more international focus - Fraser explained, 'I'm a storyteller, I want to tell stories about all kinds of people, from all over the world, .. . [my stories] all have in common the idea of connection, across suburbs, national boundaries, generations, emotional barriers . . It's what I do, I connect'. Fraser's concern 
is less with defining a nation than in establishing communications within and between nations. According to Fraser, 'New Zealand really has begun to own its place as a Pacific nation, culturally at least, and with that we're able to speak with a real athleticism and confidence. It's exciting, but we have a long way to go'?

For the writers associated with the cultural nationalism of the midtwentieth century, the nineteenth-century colonists had achieved only a physical migration during their shift from Britain to Aotearoa New Zealand: their bodies resided in this country but not their spirits. Curnow suggested that the 'recoil of the imagination from realities' which he identified in early New Zealand writing was transmitted to subsequent generations, and it would be some time before writers appeared who 'could express what it meant to be or to become a New Zealander'. ${ }^{8}$ Curnow's formula for the expression of New Zealandness was to focus on the fact that 'the best of our verse is marked or moulded everywhere by peculiar pressures - pressures arising from the isolation of the country, its physical character, and its history'. Writers' subsequent focus on a reality defined by the 'local and special' 10 enabled, on the one hand, the creation of a vital national literature; but on the other hand, it fostered essentialism and the privileging of particular categories. Notable exclusions from the new canon were, initially, women and Maori writers, and genres such as science fiction. One of New Zealand's most internationally successful writers, Ngaio Marsh, has a relatively modest reputation in her home country. Her choice of the detective genre, in which both characters and settings are largely British, as well as her many years spent living abroad, have seen her valued in New Zealand more for her local work in the theatre than for her literary contribution. The entry on Marsh in The Oxford Companion to New Zealand Literature implies a failing or lack of abilities as a fiction writer when it suggests that the English settings of her detective fiction "provided an escape from the more demanding task of establishing a New Zealand novel tradition'. ${ }^{11}$ Yet this complaint really has more to do with the genre in which Marsh wrote than with the quality of her writing since British detective fiction is an imported form offering little to the nationalist project.

In recent decades the concepts of authenticity and essentialism have been the subject of ongoing critical debate. Numerous critics, particularly those working in the fields of postcolonial and feminist studies, have attacked the fixity and perceived 'realness' associated with these notions. For Salman Rushdie, essentialism is 'the respectable child of old-fashioned exoticism. It demands that sources, forms, style, language and symbol all derive from a supposedly homogeneous and unbroken tradition'. ${ }^{12}$ Essentialism's threat lies in its ability to imprison a subject within a particular framework, often an oppressive one, denying change, flux, or the freedom of choice. 
However, critics such as Gayatri Chakravorty Spivak have attempted to salvage essentialism from these critiques by arguing that it can become an empowering force if used strategically. ${ }^{13}$ Trinh T. Minh-Ha points out that,

Every path I/i take is edged with thorns. On the one hand, i play into the Savior's hands by concentrating on authenticity, for my attention is numbed by it and diverted from other important issues; on the other hand, i do feel the necessity to return to my so-called roots, since they are the fount of my strength, the guiding arrow to which i constantly refer before heading for a new direction. ${ }^{14}$

The paradox of essentialism is that although its formulations of fixed, inherent qualities are potentially disempowering, the sense of an authentic heritage provides a grounding framework necessary for a cohesive sense of identity. The question seems to be how to balance a sense of belonging to a tangible heritage with the autonomy to realize a self potentially outside traditional categories. We might also ask how we can negotiate the homogeneity and exclusivity inherent in communal groups so that marginalized voices can be heard.

Recent fiction by authors such as Fraser, Paula Morris and Eleanor Cattan reveals an underlying concern with new modes of national being and provides a useful starting point for studying how notions of identity might be changing. Fraser's protagonist in No.2 identifies the way identity can be thought of as a performance, recalling Judith Butler's seminal work in which she suggests we reconsider identity 'as an effect', as something 'produced or generated' by context, rather than as something authentic or inherent. ${ }^{15}$ The notion of identity as performative is hardly new - discussions of the 'myth' of Janet Frame, for example, have frequently highlighted the performative nature of her writing persona ${ }^{16}$ - but what is new is its representation in popular New Zealand writing. This suggests the increasing relevance of an alternative model of identity based on choice, self-creation and fluidity, allowing a subject to inhabit a variety of roles depending on the demands of the situation. Articulations in recent writing regarding changes in the way we not only think about identity, but inhabit it, provide crucial insights, particularly because they point to identities previously marginalized by the emphasis placed on authenticity. ${ }^{17}$

In the twenty-first century, there is increasing recognition that the culture of Aotearoa New Zealand is influenced by global forces, rather than being the isolated island nation of Curnow's formulation. In 2002, writer and literary scholar Patrick Evans commented that, 'In the last decade such substantial changes have been made to the ways in which New Zealand literature is thought of and produced that the era is obviously epochal, the point at which, 
some might argue, the culture has moved beyond its postcolonial moment and into the global. ${ }^{18}$ Evans identifies Elizabeth Knox as representative of the universalizing processes in recent New Zealand fiction, which is increasingly free of reference to its country of origin, and argues that the price of telling stories with an international focus is the loss of connection between an individual writing sensibility and a meaningfully localized world. For Eleanor Cattan, author of The Rehearsal (2008), however, the fiction Evans describes does not involve 'placelessness' so much as a particular sort of engagement with place. Cattan notes that,

There was an essay about New Zealand writing published by a New Zealand academic about 10 years ago, where he criticised New Zealand writers for writing what he called "global literature" - this kind of "placeless", I think that was the word he used - placeless literature that wasn't really about New Zealand or New Zealand-ness: it didn't really engage with what it meant to be a New Zealander. And in one way, my book is a total exponent of that idea - and in another way, it's not at all. ${ }^{19}$

Like Fraser, Cattan seems to be suggesting that stories with an international focus do not relinquish their connection with what it means to be a New Zealander simply through not being set in this country, because the very condition of being a New Zealander involves a diverse range of international communications.

If New Zealand possesses an increasingly global outlook, immigration is making multicultural frameworks increasingly relevant. Alison Wong, a New Zealander of Chinese heritage, has won awards for her poetry and has recently published her first novel As the Earth Turns Silver (2009), which won the 2010 New Zealand Post Book Award for Fiction. Jacob Rajan, a New Zealander of Indian heritage, has followed up on the success of his one-man show Krishnan's Dairy (1997) with The Candlestick Maker (2000), The Pickle King (2002) and The Guru of Chai (2010). Stanley Makuwe is a Zimbabwean playwright whose The Dead Shall Rise Again (2007) made it to the Highly Commended List in the BBC International Playwriting competition and whose Overthrown (2007) was banned by the Zimbabwean government on its first night. Makuwe recently immigrated to New Zealand and observes the influence this shift is having on his work: 'My mind was always home even though I was physically here,' but 'Now that I have accepted the fact that I am here to stay, I can write stories with African and New Zealand connection'. ${ }^{20}$

The increasingly diverse composition of New Zealand society, a growing sense of independence from the colonial past and the quest for advantage in the globalized market are identified in a 2004 report published by the 
Human Rights Commission as the dominant forces shaping ideas about identity in Aotearoa New Zealand. A range of high-profile developments have focused attention on New Zealand's social and cultural diversity: a major campaign was launched for a new national flag; the Tourism Board initiated a promotion of Maori tourism operators with the mass distribution of a Rough Guide To Maori New Zealand to households in the United Kingdom; Tana Umaga became the first New Zealand Samoan captain of the All Blacks, and Beatrice Faumuina, of Samoan descent, carried the New Zealand flag at the opening ceremony of the Olympics; cultural festivals such as the Chinese New Year, the Pasifika festival, St Patrick's Day, Matariki and Diwali attract hundreds of thousands of New Zealanders in an increasing number of centres; Creative New Zealand adopted a new strategic plan which sees the development of a cultural diversity strategy as one of its key outcomes; and in 2005 the Ministry for Culture and Heritage began its on-line encyclopaedia, Te Ara, focusing on the stories of New Zealand's diverse peoples. ${ }^{21}$

New Zealand is increasingly part of a global community and the popularity of novels such as Elizabeth Knox's The Vintner's Luck (1998) and Paula Morris' Trendy But Casual (2007) suggests a certain willingness to accept writing that deviates from traditional concepts of New Zealand literature. However, Knox's novel also provoked substantial critical furore over its international setting and Morris continually has to field questions regarding her identity as a New Zealand writer. The epochal moment identified by Evans appears to involve a curious oscillation between writers who defy traditional notions about what constitutes New Zealand literature by interrogating authenticity and their audience, willing to read such works while simultaneously expressing unease about them. Literary models based on the local and the specific, and identity frameworks that assume authenticity and essentialism may be inadequate in a new century marked by multiculturalism and globalization, but there is still a level of discomfort regarding the adoption of new modes of writing and being.

Shannon Forbes points out that identity is comprised of many selves all 'instituted and de-instituted according to the repetition (or lack thereof) of the subject's external actions'. ${ }^{22}$ The place of repetition in the construction and maintenance of identity reveals how identity is constantly under threat, for what happens when actions fail to repeat, or if what is repeated subverts the intended performative purpose? Identity is always at risk and expressions of anxiety about New Zealand cultural identity have become commonplace. In 2006 for example, a Wellington production of the children's play The Last Moa inspired considerable discomfort for reviewer John Smythe, who called his piece "Outrage at Downstage". The outrage was that Tama the Moa, a large flannel puppet, was performed by an actor with an American 
accent. Although he admits that the actor did a fine job, Smythe expressed both anger and consternation as to why an American actor and accent was used to represent 'our own native fauna'. For Smythe, theatre presents 'great opportunities to stake a claim for our own cultural identity in the face of a constant TV and movie diet of American product' and he concluded the review by insisting that any 'American actor who wants to take a Kiwi role in a New Zealand play may only do so if he can get the voice right'. ${ }^{23}$ But what does it mean to get the voice right? What does a 'real' New Zealand voice sound like? Apparently Smythe did not stop to think that perhaps the actor playing the Moa was not an American actor at all, but a New Zealander with an American accent. ${ }^{24}$

C.K. Stead famously challenged Keri Hulme's right to identify and write as Maori by suggesting that her substantially European, English-speaking upbringing, coupled with the fact that she is 'only' one-eighth Maori, invalidates her position as a Maori writer eligible for the Pegasus Prize. Recent writers such as Knox, Morris and Catherine Chidgey, whose decision to set their novels in international locales and use protagonists who are not New Zealanders, pose similar challenges to the identity frameworks long governing New Zealand writing. Morris' decision to live and work in the United States, the foreign settings of many of her novels, and her deviation from the traditional frameworks of Maori writing, have seen her constantly face questions regarding her identity. In one interview she responds to the inevitable question by saying 'I'm a New Zealander, so that makes me a New Zealand writer - right? ${ }^{25}$ This would appear to be a reasonable reply for a writer born and raised in New Zealand with both Maori and Pakeha heritage. Yet Morris' failure to adhere to entrenched notions about what constitutes New Zealand literature continues to cause discomfort. A Sunday Star Times reviewer of Trendy But Casual admits that 'As far as I know, there's no law that says New Zealand authors have to write about New Zealand', but nevertheless confesses to being 'surprised to find no trace of Godzone in Paula Morris's latest book . . . Unless you count the mention of a chocolate fish'. The novel's American vernacular is 'pitch-perfect' but there is a certain ambivalence in the reviewer's conclusion that 'You'd never pick she was a Kiwi girl from the idioms in this book'. ${ }^{26}$ As in "Outrage at Downstage", this review demands a certain degree of authenticity, a "right voice' that clearly conveys what it means to be a New Zealander.

Unlike Keri Hulme, who said 'I think of myself as Maori rather than Pakeha . . . that's the side I learnt to tell stories from', ${ }^{7}$ Morris expresses a dislike of essentialist labels. In an unpublished interview with Ann Pistacchi she admitted she felt ambivalent about being considered a fullfledged member of what she calls the 'Maori writer's club'. ${ }^{28}$ The prospect of being categorized as a 'New Zealand writer' or as a 'Maori writer' seems 
to provoke discomfort for Morris, recalling Judith Butler's confession that 'the prospect of being anything, even for pay, has always produced in me a certain anxiety' because to claim 'that this is what I am is to suggest a provisional totalization of this "I", ${ }^{29}$ In Hibiscus Coast (2005) Morris moves away from the totalization of identity to portray identities which are created and performed - a development which is shown to be both liberating and limited. One character is perfectly at ease with being what she refers to as a 'Pacific Rim hybrid', while another character's dislocation from the traditional cultural frameworks that support identity leaves her destabilized and vulnerable. The novel explores a particularly twenty-first century notion of fluid identity and its plot, centred upon an art forgery ring, similarly challenges concepts of authenticity and value. ${ }^{30}$

The novel's main protagonist, Emma, is a New Zealander of Chinese and Maori heritage whose identity defies conventional categorizations. In Auckland 'Emma's accent sounded right, but her face never seemed to fit', yet in China she discovers that her looks 'fit' but her speech does not. She comes to suspect that 'both sides of the family thought her a mongrel'. ${ }^{31}$ Although Emma makes a pilgrimage of sorts to Shanghai, its purpose is not,

to ruminate over what it meant to be an Asian and a New Zealander at the same time. She'd always scoffed at these kind of quests, rolling her eyes at the New Zealanders she met in London off to track down ancestral homes in Scotland or someone with a vaguely similar surname in the Isle of Man. They didn't belong in Britain any more than she would in China, and all the root-digging in the world wouldn't unearth any home truths. ${ }^{32}$

For Emma, there is no fixed identity to be reclaimed by tracing her heritage, no profound secrets to be revealed by digging for home truths. Although she does attempt to perform a traditional Chinese ceremony in honour of her dead mother, Emma's doubts about its effectiveness stand in stark contrast to the bone people's protagonist Joe, whose digging literally unearths a home truth leading to his personal healing and the regeneration of the dormant spirit of the land.

Emma appears content to acknowledge herself as neither Chinese nor Maori but as 'some sort of Pacific Rim hybrid', ${ }^{33}$ thus aligning herself with a concept deemed capable of creating new, transcultural forms of identity. By mingling the old and the new, hybrid identities conflate different cultural traditions into an original 'mixed culture'. In claiming a hybrid identity Emma rejects being defined or represented by her cultural background. The concept of hybridity is considered emancipatory in that it liberates the subject from a sense of dislocation and alienation. But of course the hybrid 
itself is a category, for although hybridity critiques notions of authenticity, it simultaneously produces new forms. Hibiscus Coast seems to respond to this dilemma by emphasizing a crucial difference between an essentialist identity and a hybrid one: choice. One of the novel's minor characters is Derek, who sees his Dutch and Maori ancestry as providing him with a range of options from which to construct an identity. His 'practical Dutch part' coexists with his 'fun-loving Maori side', and although these are stereotypical articulations of cultural identity, there is still a sense that Derek is aware of a choice of cultural referents from which he can draw. Derek does not reject his Dutch and Maori heritage as spaces he cannot inhabit because of his either/or status but happily draws from both.

Hybridity also features in Briar Grace Smith and Jo Randerson's 1999 play The Sojourns of Boy, in which the protagonist Runty (a young Maori boy adopted by Pakeha parents) wonders 'Who am I now who am I who am I?'34 A ghostly figure, Runty describes feeling trapped in a hybrid world between the real and the supernatural, a dislocation that seemingly springs from his adoption and resulting estrangement from his Maori heritage, since his mild speech defect is particularly apparent when he attempts to speak Maori. Runty exists between two different cultures and his attempts to negotiate the conflicts between them results in what Marc Maufort calls 'an epiphanic sense of reconciliation' when Runty performs a resurrection in a hybrid blend of Maori and English. ${ }^{35}$

Homi K. Bhabha's work posits hybridity as the antidote to essentialism since it takes elements from each subject position in a binarized discourse to create an indeterminate position capable of challenging hegemonic cultural structures. The hybrid identity inhabits a liminal space between categories, what Bhabha calls the 'third space' ${ }^{36}$ Hybridity's ability to disarm binarized discourse is capable of provoking significant discomfort, evident not only in the context of how the term is used now but also in its earlier employment. An editorial from the New Zealand Observer in 1893 illustrates a colonial construction of 'pure' cultural identity and the fear of hybridity:

There is a sentiment amongst the people at large which has almost become a watchword or motto: 'New Zealand for the New Zealanders.' Our ambition is assuredly not to colonize our country with Chinese, or Kanakas or Austrians. Neither are we ambitious to have a mixed race - a hybrid or mongrel people of no nationality in particular, but in reality a mixture of all. On the contrary, we are all anxious to preserve the purity [of] our race. ${ }^{37}$

It is to combat this sort of rationale that so many writers insist that affirmations of hybridity are useful in the arena of cultural politics. Such affirmations are proclaimed precisely because the varieties of cultural borrowing involved undermine the case for a pure culture or identity. 
The freedom to self-create without limitation renders the 'inauthenticity' of a performed identity a strength rather than a weakness. In a 2009 Listener article, Siobhan Harvey points out that performance poet Tusiata Avia's latest offering, Bloodclot, is marked by depictions of the protagonist Nafanua 'like Avia in her stage show - donning different personas. The result is a work containing 50 poems with titles such as Nafanua is a girl from Aranui and Nafanua becomes a surgeon for the day'. ${ }^{38}$ Nafanua's journeys involve her leaving the places which might define her in order to try on different identities. In Nafanua and the New World, she is 'from nowhere driving out into the world as far away from Aranui as she can go/Nafanua from Pulotu driving out into the world and all the things that make her beautiful spin away like hubcaps'. In Nafanua talks about her body, her trip to America means assuming an entirely different self:

In my hair I have someone with a rake making boundaries on my scalp

this way that way this way

the result will be great

like Entertainment Tonight

and my body, the one I will have to lose when I become an

Amerikan

the one that fits into plane seats with real pain,

that body will have to go.

When I get to Amerika it will be unbuckled like saddlebags at the border

and like Miss Amerika, boiled down and nice and twang, I'll hand over my visa

and they'll say, Welcome, Leeza, we've prepared a place for you.

Nafanua talks about her body recalls Sia Figiel's Songs of the Fat Brown Woman (1998), but whereas Figiel celebrates a generous figure in defiance of 'miss universe on tee vee', ${ }^{39}$ Avia represents the beauty pageant body as a sort of costume her protagonist can assume in order to gain access to a new 'place'. While the poem displays an undeniable irony about the process of becoming an 'Amerikan', it also conveys a sense of liberation in that neither this nor any other identity is inaccessible. Nafanua can be from a specific place and nowhere, just as she can be a surgeon and an American beauty queen.

Eleanor Cattan's novel The Rehearsal employs the motif of performance to illustrate the essentially acted nature of identity as well as reality. The novel depicts a school coping with the revelation of a sexual relationship between a student and a teacher, and the local drama school's decision to improvise around the scandal for their end-of-year show. Stanley, a new 
student at the drama school, explicitly draws out the connections between performance and identity. He notes that 'Girls were always acting ... Girls could distinguish constantly and consciously between themselves and the performance of themselves, between the form and the substance.' ${ }^{40}$ The schoolgirls assume a series of changing identities in their progress towards their adult selves: 'Victoria's perspective on her little sister's life is always that of a recent veteran, knowing and qualified and unshockable. It is as if, at each new stage, Isolde merely picks up another hand-me-down costume that Victoria has grown out of.' ${ }^{41}$

The line between the authentic and the spurious is profoundly destabilized by Cattan, who uses theatrical conventions, heightened tone and unexpected diction to confound the line between reality and performance. One section seems to depict two characters discussing the sex scandal, a realism which is undercut by the insertion of:

This girl is good at voices. She actually wanted to be Isolde, because Isolde has a better part, but this girl is pale and stringy and rumpled and always looks alarmed, which are qualities that don't quite fit Isolde, and so she plays Bridget instead. In truth it is her longing to be an Isolde that most characterises her as a Bridget: Bridget is always wanting to be someone else. ${ }^{42}$

Cattan's fictional protagonists are representations of real people involved in a fictional process of representing real people, a hall-of-mirrors sequence which casts light on the essentially constructed nature of all identity. In an interview Cattan admits to 'a real attraction to theories of performance', which she identifies as 'the theoretical ideas behind the book'. Her belief 'that we do perform our identities' means that when she encountered criticism as to 'are they on stage or aren't they, my answer would be, yes - but not in a way that's peculiar to the book'. Cattan suggests that,

One thing[] that's weird about growing up in the world right now - being of my generation - is that you really can choose who you want to be. People my age have such a keen awareness of "this is what an emo is" or "this is what a punk rocker is". If you make all the choices - if you go down the list and you tick 'yes' to all these questions - then you become that person. We have so many choices about how we choose to dress ourselves or how we choose to do our hair - reinventing yourself is so possible. If you think back a hundred years, it was impossible. It's such a modern phenomenon. ${ }^{43}$

The Rehearsal is defiantly unrealistic, even postmodern, and offers a radical departure from the realism which marks much of twentieth-century New Zealand fiction. 
The constructed nature of identity is also a feature of Lloyd Jones' novel, Mister Pip (2006), which revolves around a white man reading Dickens' Great Expectations to a group of native children in Bougainville during a period of civil war. In an interview, Jones suggests that Dickens' protagonist's "invitation to go up to London and turn himself into a "gentleman" is similar to the challenge we all face: to make ourselves into something, ${ }^{44}$ Not the least of Jones' achievement in writing Mister Pip is to use the narrative voice of an adolescent female native to Bougainville. Given the controversy provoked by Hulme's decision to write as Maori, especially given the fact that she does have Maori heritage, Jones' escape from criticism in this regard suggests a change in attitudes regarding who can inhabit particular identities. The different versions of Great Expectations in Mister Pip - the one Watts reads to his class, the missing one that the children try to recreate, the one Watts reads to the rebels, and of course, the original version by Dickens - are matched by several versions of Watts himself. At first he is the local eccentric, and then he is a storyteller, teacher, a sort of substitute father, martyr, and actor. Just as Dickens' Pip changes his identity from orphan to gentleman, Watts assumes a series of roles all as 'real' as the other. Identity changes because of circumstance: when Watts reads Great Expectations he becomes a storyteller; and when he works at the school he becomes a teacher. This malleability of self is shown in a more disquieting light when Watts' wife has a breakdown and takes on the identity of the Queen of Sheba.

The liberation offered by performative identity goes hand in hand with limitation. Although Morris' Hibiscus Coast suggests Emma is liberated from an either/or paradigm by embracing hybridity, her ex-boyfriend Siaki seems to find only isolation and disenchantment in his performed identity. A young man of Samoan heritage, Siaki decides that,

Just because he'd grown up in a state house and attended a state school, his beginnings didn't have to define him. The first step was having sufficient vision to see himself differently. The value of things was informed by how they were positioned, how they were perceived. The value of a person, Siaki decided, was no different. ${ }^{45}$

Siaki's insight into a created self sees him transcend the limitations of his socio-economic background, but at a cost. Value, according to Siaki, lies not in the traditions of home and community that his parents represent, but in capitalist attitudes of materialism and success.

Siaki's pride in being a 'self-made' man stems not only from his success in education and employment but from the way he has created an identity that is not based on his heritage. At the real estate firm where he works, Siaki has experienced racism and finds that many clients never grow comfortable 
doing business with him because of his age and skin colour. He resents the assumptions about his junior status in the firm - that he is the advance guard only, the messenger. ${ }^{46}$ His own colleagues are too impatient to learn how to pronounce his name and he is nicknamed Sammy. Siaki realizes that in the world of white business he is not Siaki Samuels the sales guy, but 'Sammy Samuels, the Samoan sales guy'. ${ }^{47}$ Siaki realizes that the first step to changing his identity is to change how he perceives himself, so he devotes time and energy to studying the mannerisms of his business colleagues, learning how to appear a successful confident business man. When he appears to be one, he is one. Yet despite achieving material and career success, Siaki is not a happy or well-adjusted figure. Although he has escaped the stereotyped position thrust upon him by racist perceptions, the liberation offered by the process of self-creation, Morris suggests, comes at a cost.

Personal and national identity are always haunted by ambivalence since the events, narratives and traditions of the past, which are the material used to forge an identity in the present, seem to promise a stable point of reference while also being subject to precarious ongoing enunciation. The problem in any postcolonial nation is that conflicted histories problematize the storehouse from which we gather our identity material. Although Bhabha argues for the emancipatory potential of hybridity because of its ability to confound concepts of identity based on binary categories, this does not override the fact that the hybrid is itself a category capable of miring a disoriented subject within a liminal space. Similarly, the value of performative identity relies on an empowering sense of choice and creativity, but this empowerment is potentially accompanied by anxieties surrounding inauthenticity. In Hibiscus Coast, Emma's acceptance of her hybrid identity and her investigations into authenticity through artistic forgery are a source of strength as well as weakness. Emma discovers she need not adhere to either Maori or Chinese notions of appearance and behaviour, nevertheless it is difficult to ignore the fact that she is friendless, isolated and far from happy. Siaki's performed identity sees him achieve material and professional success at the cost of what we might be tempted to think of as his 'true self'. But what is this true self and how to access it? Perhaps the answer lies not in eluding categorization or defying authenticity but in embracing multiplicity. In this context, Siaki's problem lies in his inability to juggle more than one role. Perhaps if he were the hot-shot businessman Sammy Samuels pursuing professional goals as well as Siaki Samuels, the often frustrated yet ultimately loving and loved member of an extended Samoan family, his story might be a less disquieting one.

The brief survey I have offered here is necessarily open-ended and provisional. There is a rethinking of identity taking place as multiculturalism 
and globalization make their various effects felt, but just what this might mean for New Zealanders as members of a nation, and not just readers of literature, remains to be further explored. If literary nationalism made itself felt during the middle decades of the twentieth century, and if postcolonialism and feminism marked the latter decades, perhaps the first movement of the twenty-first century in Aotearoa New Zealand might prove to be performatism, a term first used by Raoul Eshelman in 2000. Eshelman posits performance as the antidote to postmodernism's modes of dispersal, deconstruction and proliferation. The concept of performance, Eshelman suggests, 'serves neither to foreground nor contextualize the subject, but rather to preserve it: the subject is presented (or presents itself) as a holistic, irreducible unit that makes a binding impression on a reader or observer'. ${ }^{48}$ This holistic incarnation does not offer a semantically differentiated surface that can be absorbed into the surrounding context, so that the new subject always appears to be identical with the things it stands for. Rather, the result is the creation of 'a refuge in which all those things are brought together that postmodernism and poststructuralism thought definitively dissolved'. If the performative subject expresses itself 'in holistic performances in which it believes', what happens when those performances are recognized as such? Might we then have a model for a multiplicity of selves adaptable to changing environments and circumstances yet cohesive enough to withstand the dispersals and disintegrations of the postmodern and the postcolonial?

The exploration of performative identities challenging fixed notions of authenticity and essentialism brings us always back to the implications of this mode of being. Authenticity clearly relies on exclusion, since legitimacy and purity must be measured against something. This suggests that a reclamation of the inauthentic via performance introduces identities previously omitted, sidelined or disparaged. Essentialism's reliance on inherent qualities precludes freedom of choice, which performative identity is capable of reinstating. As we move further into the twenty-first century, writers who choose to tackle themes of identity in their writing will take up a project both challenging and contested, a project which continues to be of the utmost importance to us as members of a nation and as individuals striving to develop meaningful relationships with that nation and with ourselves. Interestingly enough, Curnow seems to be implicated in both authentic and performative models of identity, since in 1945 he claimed that 'New Zealand doesn't exist yet, though some possible New Zealands glimmer in some poems and on some canvasses. It remains to be created - should I say invented - by writers, musicians, artists, architects, publishers; even a politician might help - and how many generations does that take?' ${ }^{49}$ 
1 Keri Hulme, the bone people, Auckland, 1985, p.61.

2 Toa Fraser, No.2 in Two Plays, Wellington, 2007, p.13.

3 Mark Williams, Leaving the Highway, Auckland, 1990, p.85.

4 Joy Cowley, 'We Are The Bone People', Listener, 107, 2309 (12 May 1984), p.60.

5 Sandi Hall, 'Conversation at Okarito,' Broadsheet, 120 (June 1984), p.20.

6 Merata Mita, 'Indigenous Literature in a Colonial Society,' The Republican, 52 (1984), p.4.

7 Toa Fraser, Interviewed by Renee Liang, The Big Idea/Te Aria Nui, 10 September 2009, http://www.thebigidea.co.nz/news/blogs/talkwrite/2009/sep/60230-cultural-storytellers-toa -fraser, accessed 12 January 2010.

8 Allen Curnow, The Penguin Book of New Zealand Verse, Harmondsworth, 1960, p.20.

9 Curnow, p.17.

10 Ibid.

11 Nelson Wattie, 'Marsh, Ngaio', in Roger Robinson and Nelson Wattie, eds, The Oxford Companion to New Zealand Literature, Auckland, 1998, available at New Zealand Book Council website, http://www.bookcouncil.org.nz/writers/marshn.html, accessed 15 February 2010.

12 Salman Rushdie, 'Commonwealth Literature Does Not Exist', Imaginary Homelands: Essays and Criticism, London, 1991, p.67.

13 See Gayatri Chakravorty Spivak, 'Subaltern Studies: Deconstructing Historiography', in Donna Landry and Gerald Maclean, eds, The Spivak Reader, New York, 1996, pp.203-36.

14 Trinh T. Minh-Ha, 'Writing Postcoloniality and Feminism', in Bill Ashcroft, Gareth Griffiths and Helen Tiffin, eds, The Post-colonial Studies Reader, London, 1995, p.268.

15 Judith Butler, Gender Trouble: Feminism and the Subversion of Identity, New York, 1990, p.147.

16 For an in-depth study of the 'myth' of Janet Frame see Maria Wikse, Materialisations of a Woman Writer: Investigating Janet Frame's Biographical Legend, Oxford and New York, 2006.

17 Recent comments made by Paul Henry regarding Governor-General Sir Anand Satyanand highlight the way that identities not adhering to a particular understanding of New Zealandness can be sidelined, excluded and disparaged. During his morning Breakfast show, Henry queried Prime Minister John Key about the appointment of the next Governor-General and asked, 'Are you going to choose a New Zealander who looks and sounds like a New Zealander this time ... Are we going to go for someone who is more like a New Zealander this time?' Sir Anand was born and raised in New Zealand by Fijian Indian parents. Another recent example involved Jacinta Lal, a blue-eyed blonde who was accused of not looking Indian enough after winning a Miss India NZ beauty contest. Indian spectators of Lal's win laid complaints about her eligibility, and Lal, whose father is Fijian Indian while her mother is of European heritage, told the New Zealand Herald that she had heard people saying 'I wasn't Indian-looking enough to win the pageant.' She went on to suggest that 'There is no difference between what Paul Henry is saying and what those select few Indians were saying.' To view the Breakfast show segment in which Henry questions Sir Anand's origins visit Indian Weekender, http://www.indianweekender.co.nz/Plugins/Video/Default.aspx?VideoID=374\&Video CategoryID=9\&Title=Paul-Henry-questions-Sir-Anands-origins. For the full story about Jacinta Lal see 'New Zealand Indian in Beauty Contest "Not Indian Looking Enough", 
3News website, 13 October 2010, http://www.3news.co.nz/NZ-Indian-in-beauty-contest -not-Indian-looking-enough/tabid/423/articleID/181091/Default.aspx, accessed 16 October 2010.

18 Patrick Evans, “'Spectacular Babies”: the Globalisation of New Zealand Fiction', Kite, 22 (2002), p.5.

19 Eleanor Cattan, Interviewed by Rachael Beale, Belletrista (n.d.), http://www.belletrista .com/2009/issue1/features_2.html, accessed 8 February 2010.

20 Stanley Makuwe, Interviewed by Renee Liang, The Big Idea / Te Aria Nui, 19 October 2009, http://www.thebigidea.co.nz/news/blogs/talkwrite/2009/oct/61752-cultural -storytellers-stanley-makuwe-and-alex-broun, accessed 15 February 2010.

21 Human Rights Commission, 'Race Relations in 2004', Annual Review of Race Relations (March 2005), p.15. Available at: http://www.hrc.co.nz/home/hrc/resources/resources .php\#racerelations1.

22 Shannon Forbes, 'Performative Identity Formation in Frank McCourt's Angela's Ashes: A Memoir', Journal of Narrative Theory, 37, 3 (Fall 2007), p.477.

23 John Smythe, 'Outrage at Downstage', Theatreview: The New Zealand Performing Arts Review, 16 April 2006, http://www.theatreview.org.nz/reviews/review.php?id=156, accessed 20 July 2009.

24 Tama the Moa was played by Gene Alexander, a New Zealand resident born in Russia who spent his teenage years in the United States.

25 Interviewed by Amy Brown, The Lumière Reader, 28 April 2007, http://www.lumiere .net.nz/reader/item/954, accessed 15 April 2008.

26 Zara Potts, Review of Trendy But Casual, Sunday Star Times, 1 April 2007.

27 Hulme quoted in Aorewa Pohutakawa McLeod, 'Hulme, Keri', in Pamela Kester-Shelton, ed., Feminist Writers, Detroit, 1996, p.244.

28 Ann Pistacchi, 'Reading Paula Morris in the Heart of Nepantla', Journal of New Zealand Literature 24, 2 (2007), pp.98-116.

29 Judith Butler, 'Imitation and Gender Subordination', in Diana Fuss, ed., Inside/Out Lesbian Theories, Gay Theories, New York, 1991, pp.13, 15.

30 The material here discussing Hibiscus Coast is largely taken from my article, 'Urban Spaces, Hybrid Faces: Rethinking Identity in Paula Morris's Hibiscus Coast, in Anna Jackson and Jane Stafford, eds, Essays on Contemporary New Zealand Literature, Wellington, 2009, pp.124-41.

31 Paula Morris, Hibiscus Coast, Auckland and New York, 2005, p.16.

32 Ibid., p.127.

33 Ibid., p.217.

34 Briar Grace-Smith and Jo Randerson, The Sojourns of Boy, ts., Wellington, 1999, p.67.

35 Marc Maufort, 'Painful Homecomings: Family Fractures in Contemporary Pakeha Dramaturgies', in Marc Maufort and David O'Donnell, eds, Performing Aotearoa: New Zealand Theatre and Drama in an Age of Transition, New York, 2007, p.125.

36 Homi K. Bhabha, The Location of Culture, London, 1994.

37 Editorial, New Zealand Observer, 27 May 1893, p.2.

38 Siobhan Harvey, 'Goddess of Poetry', Listener, 217, 3588 (14 February 2009), http://www .listener.co.nz/issue/3588/artsbooks/12766/goddess_of_poetry.html, accessed 5 January 2010.

39 Sia Figiel, 'Songs of a Fat Brown Woman', in To a Young Artist in Contemplation: Poetry and Prose, Suva, 1998, p.7.

40 Eleanor Cattan, The Rehearsal, Wellington, 2009, p.77. 


\section{Journal of New Zealand Studies}

41 Ibid., p.56.

42 Ibid., p.15.

43 Eleanor Cattan, Interviewed by Rachael Beale, Belletrista (n.d.), http://www.belletrista .com/2009/issue1/features_2.html, accessed 8 February 2010.

44 'Lloyd Jones on the Success of Mister Pip', interview posted on The Man Booker Prizes website (n.d.), http://www.themanbookerprize.com/perspective/articles/89, accessed 12 January 2010.

45 Morris, p.114.

46 Ibid., p.86.

47 Ibid., p.87.

48 Raoul Eshelman, 'Performatism, or the End of Postmodernism', Anthropoetics - The Electronic Journal of Generative Anthropology, 6, 2 (Fall 2000/Winter 2001), available at http://www.anthropoetics.ucla.edu/ap0602/perform.htm, accessed 12 January 2010.

49 Allen Curnow, Look Back Harder: Critical Writings, 1935-1984, ed. Peter Simpson, Auckland, 1987, p.77. 